\title{
JAMES WATERMAN GLOVER-IN MEMORIAM
}

James Waterman Glover, emeritus professor of mathematics at the University of Michigan, died in Ann Arbor, Michigan, on July 15, 1941. In his passing, actuarial and statistical science has lost one of its most distinguished pioneers.

Professor Glover was born at Clio, Michigan, on July 24, 1868. He was graduated from the University of Michigan with the class of 1892 , where he came under the influence of $\mathrm{F} . \mathrm{N}$. Cole, and received his doctor's degree from Harvard University in 1895, being the first one to do his thesis work under the supervision of Maxime Bôcher; his thesis subject was Properties of Solutions of the Partial Differential Equation $\Delta y+k y=0$. He then returned to the University of Michigan as a member of the Department of Mathematics, holding the various ranks, Assistant Professor in 1903, Junior Professor in 1906, and Professor in 1911, until he retired in 1938. He was chairman of the Department of Mathematics from 1927 to 1934. During the years 1930 to 1932 he had leave of absence, and served as president of the Teachers' Insurance and Annuity Association of America. He was a member of the Council of the American Mathematical Society from 1927-1929.

Beginning in 1902 with a course in actuarial theory, Professor Glover gradually developed courses in the mathematics of finance, life insurance, and statistics, at the University of Michigan. As a consequence of the training afforded by these courses, he was able to place hundreds of students in responsible positions with life insurance companies and state departments. At the time of his retirement about two hundred of his former students, many of them executives of major insurance companies, gave a dinner in Chicago honoring him. At this meeting a fellowship in insurance, bearing his name, was established.

In his administrative capacity he not only built up the work in actuarial mathematics and mathematical statistics at the University, but was also responsible for greatly strengthening the work of the Department in other branches by the addition of promising young men.

His activities outside of the University were numerous. He served as consulting expert for the Canadian Royal Commission on Insurance in 1896, for the Wisconsin Legislative Investigation Committee in 1906, for the Wisconsin Joint Committee on Banks and Insurance in 1907, and for numerous insurance companies. From 1910 to 1929 he served the U. S. Census Bureau as Expert Special Agent and dur- 
ing this time the United States Life Tables were prepared under his supervision.

While Professor Glover was a forceful person so far as being able to accomplish something he thought ought to be done, he was an extremely pleasant person with whom to be associated. One could oppose something he proposed to do, feeling certain it would not affect a personal friendship. He was fond of hunting and fishing and was a delightful companion on an outing. His accomplishments are a lasting monument to his memory.

Following is a list of his publications of mathematical interest:

1. On groups whose orders are products of three prime factors (with F. N. Cole), American Journal of Mathematics, vol. 15 (1893), pp. 191-220.

2. Derivation of the United States mortality table by osculatory interpolation, Quarterly Publication of the American Statistical Association, (n.s.), vol. 12 (1910), pp. 85-109.

3. A general formula for the valuation of securities, American Mathematical Monthly, vol. 22 (1915), pp. 82-88.

4. Some formulas connected with the calculation of annual dividends on the contribution plan, Record of the American Institute of Actuaries, vol. 5 (1916), pp. 37-43.

5. United States Life Tables: 1910, Government Printing Office, Washington, 1916, 65 pp., 25 life tables.

6. United States Life Tables, 1890, 1901, 1910 and 1901-1910, Government Printing Office, Washington, 1921, 496 pp., 22 diagrams, 52 graphs.

7. Tables of Compound Interest Functions and Logarithms of Compound Interest Functions (with H. C. Carver), Ann Arbor, 1921, 77 pp.

8. Tables of Applied Mathematics in Finance, Insurance, Statistics, Ann Arbor, 1923, 13+676 pp.

9. Tables of Statistical Data for the Use of Students of Mathematical and Economic Statistics (with H. C. Carver), Ann Arbor, 1923, 53 pp.

10. Interpolation, summation and graduation, chap. 3, pp. 34-61, Handbook of Mathematical Statistics, Houghton Mifflin, 1924.

11. Quadrature formulas when ordinates are not equidistant, Proceedings of the International Congress of Mathematicians, Toronto, 1924, vol. 2 .

12. Report on statistical teaching in American colleges and universities, Journal of the American Statistical Association, vol. 21 (1926).

13. An Introduction to the Mathematics of Life Insurance (with W. O. Menge), New York, Macmillan, 1935, 9+190 pp.

Peter Field 